\title{
Annual New Production of Phytoplankton Estimated from MODIS-Derived Nitrate Concentration in the East/Japan Sea
}

\author{
Huitae Joo ${ }^{1}$, Dabin Lee ${ }^{1}$, Seung Hyun Son ${ }^{2}$ and Sang Heon Lee ${ }^{1, *}$ \\ 1 Department of Ocenography, Pusan National University, Geumjeong-gu, Busan 46241, Korea; \\ huitae@pusan.ac.kr (H.J.); ldb1370@pusan.ac.kr (D.L.) \\ 2 Cooperative Institute for Research in the Atmosphere (CIRA), Colorado State University, Fort Collins, \\ CO 80523, USA; oceancolor.son@gmail.com \\ * Correspondence: sanglee@pusan.ac.kr; Tel.: +82-51-510-2256
}

Received: 25 April 2018; Accepted: 18 May 2018; Published: 22 May 2018

\begin{abstract}
Our main objective in this study was to determine the inter-annual variation of the annual new production in the East/Japan Sea (EJS), which was estimated from MODIS-aqua satellite-derived sea surface nitrate (SSN). The new production was extracted from northern $\left(>40^{\circ} \mathrm{N}\right)$ and southern $\left(>40^{\circ} \mathrm{N}\right)$ part of EJS based on Sub Polar Front (SPF). Based on the SSN concentrations derived from satellite data, we found that the annual new production (Mean \pm S.D $=85.6 \pm 10.1 \mathrm{~g} \mathrm{C} \mathrm{m}^{-2}$ year $^{-1}$ ) in the northern part of the EJS was significantly higher $(t$-test, $p<0.01)$ than that of the southern part of the EJS (Mean \pm S.D $=65.6 \pm 3.9 \mathrm{~g} \mathrm{C} \mathrm{m}^{-2}$ year $^{-1}$ ). Given the relationships between the new productions and sea surface temperature (SST) in this study, the new production could be more susceptible in the northern part than the southern part of the EJS under consistent SST warming. Since the new production estimated in this study is only based on the nitrate inputs into the euphotic depths during the winter, new productions from additional nitrate sources (e.g., the nitrate upward flux through the MLD and atmospheric deposition) should be considered for estimating the annual new production.
\end{abstract}

Keywords: new production; surface nitrate concentration; East/Japan Sea (EJS)

\section{Introduction}

Various changes in physical, chemical and biological properties have been reported in the East/Japan Sea (EJS) during last several decades [1-8]. Particularly, a dramatic change in the vertical distribution of the chemical properties and sea surface temperature of the winter and spring was observed in the southern EJS during the last few decades [2-4]. According to several reports, the chlorophyll-a, primary production, phytoplankton size, and zooplankton biomass were changed by the seawater temperature and the volume transport of the Kuroshio Current in Korean waters, including the EJS [9-13]. Moreover, changes in the number of fish caught have been observed in the EJS [14-17].

The EJS has two main water-mass properties such as cold and warm waters. A Sub Polar Front (SPF) is formed by the confluence of the warm and cold currents located at approximately $40^{\circ} \mathrm{N}[18,19]$. The different water mass leads to a gradient in environmental factors and phytoplankton dynamics in the EJS, which seems to be controlled by vertical variations in hydrographic features such as physical mixing and light-nutrient availability [20]. The vertical structure of the water column differs between the northern and southern parts of the EJS and is strongly associated with ecosystem dynamics [21].

Generally, high and frequent nitrate upward movements by vertical mixing, upwelling, and eddies are observed to be the major cause of high primary production in the EJS [4,22-24]. Recently, Joo et al. [13] observed a decreasing trend in the long-term annual primary production in the EJS 
obtained from MODIS-aqua from 2003 to 2012. Previously, they found that the decreasing annual primary production in the Ulleung Basin has a strong association with the decreasing nutrient concentrations in the euphotic water columns (0 to $50 \mathrm{~m})$ from 2003 to 2012 [6]. In general, the nitrate concentration has a negative correlation with temperature in various oceans as well as in the EJS [25-27]. Due to climate change, the increased surface temperature can form a strong stratification in the surface water, which could reduce the nitrate upward flux into euphotic depths from deep waters in the global ocean [28-30]. Therefore, ongoing climate change and subsequent strong stratifications in surface ocean waters $[28,29]$ could negatively affect the new production of phytoplankton, based on $\mathrm{NO}_{3}$ concentration and consequently affect the higher trophic levels in marine ecosystems. Generally, new production is defined as primary production based on nitrate concentration as a nitrogen source coming from deep waters to the euphotic zones, which could increase phytoplankton population size in marine ecosystems [31,32]. Currently, only a few field-measured new productions have been obtained in the EJS [2,33-36]. However, there has been no information on the temporal and spatial variation of the new production that is currently available in the EJS. In general, the nitrate concentration is known to have a significant relationship with the water temperature in the Ocean [37]. Since the phytoplankton community could have significant impacts on the temperature-nitrate relationship in the euphotic zone [38-40], we estimated sea surface nitrate (SSN) and new production based on sea surface temperature (SST) and sea surface chlorophyll (SSC) from ocean color data. In this study, the temporal and spatial variations of SSN and new production were analyzed in the EJS using a regional SSN algorithm and new production algorithm based on the ocean color data derived from Moderated-Resolution Imaging Spectro-radiometer (MODIS). The main objectives of the present study were to develop a regional algorithm of SSN and new production, detect the temporal and spatial distributions of SSN and new production, and to find a main controlling factor for the variation in new production in the EJS during the study period from 2002 to 2015.

\section{Data and Methods}

\subsection{Data}

Field-measured SSN data in the EJS were obtained from the KODC (Korea Ocean Data Center) website (http:/ / kodc.nifs.go.kr), JMA (Japan Meteorological Agency) website (http:/ /www.jma.go.jp/ jma/indexe.html), and Korea-Russia joint Cruise (EAST-1 reports). The locations of field-measured data are shown in Figure 1 and the information of the field-measured data is summarized in Table 1.

Table 1. Information for the field-measured nitrate concentrations in the East/Japan Sea (EJS).

\begin{tabular}{|c|c|c|c|c|}
\hline Data Source & Year & Month & Location & Agency \\
\hline $\begin{array}{c}\text { http: } \\
\text { / / kodc.nifs.go.kr }\end{array}$ & 2012 2015 & $\begin{array}{l}\text { February } \\
\text { April } \\
\text { June } \\
\text { August } \\
\text { October } \\
\text { December }\end{array}$ & Southwestern part & $\begin{array}{l}\text { NIFS (National } \\
\text { Institute of } \\
\text { Fisheries and } \\
\text { Sciences, Korea) }\end{array}$ \\
\hline \multirow[t]{2}{*}{$\begin{array}{c}\text { http: } \\
\text { //www.jma.go.jp/ } \\
\text { jma/indexe.html }\end{array}$} & 2005 & $\begin{array}{c}\text { January-February } \\
\text { April } \\
\text { May } \\
\text { July } \\
\text { August } \\
\text { October } \\
\end{array}$ & \multirow[t]{2}{*}{ Southeastern part } & \multirow[t]{2}{*}{$\begin{array}{c}\text { JMA (Japan } \\
\text { Meteorological } \\
\text { Agency, Japan) }\end{array}$} \\
\hline & 2006 & $\begin{array}{l}\text { February } \\
\text { April-May } \\
\text { July } \\
\text { October }\end{array}$ & & \\
\hline
\end{tabular}


Table 1. Cont

\begin{tabular}{|c|c|c|c|c|}
\hline Data Source & Year & Month & Location & Agency \\
\hline & 2007 & $\begin{array}{c}\text { January } \\
\text { April-May } \\
\text { July } \\
\text { October }\end{array}$ & & \\
\hline & 2008 & $\begin{array}{c}\text { January } \\
\text { April-May } \\
\text { July } \\
\text { October }\end{array}$ & & \\
\hline & 2009 & $\begin{array}{l}\text { January } \\
\text { February }\end{array}$ & & \\
\hline Cruise reports & $\begin{array}{l}2007 \\
2009 \\
2012 \\
2014 \\
2015\end{array}$ & $\begin{array}{c}\text { May } \\
\text { July } \\
\text { October } \\
\text { April } \\
\text { April }\end{array}$ & $\begin{array}{l}\text { Ulleung Basin and } \\
\text { Northern part }\end{array}$ & $\begin{array}{c}\text { MOF (Ministry of } \\
\text { Oceans and } \\
\text { Fisheries, Korea) }\end{array}$ \\
\hline
\end{tabular}

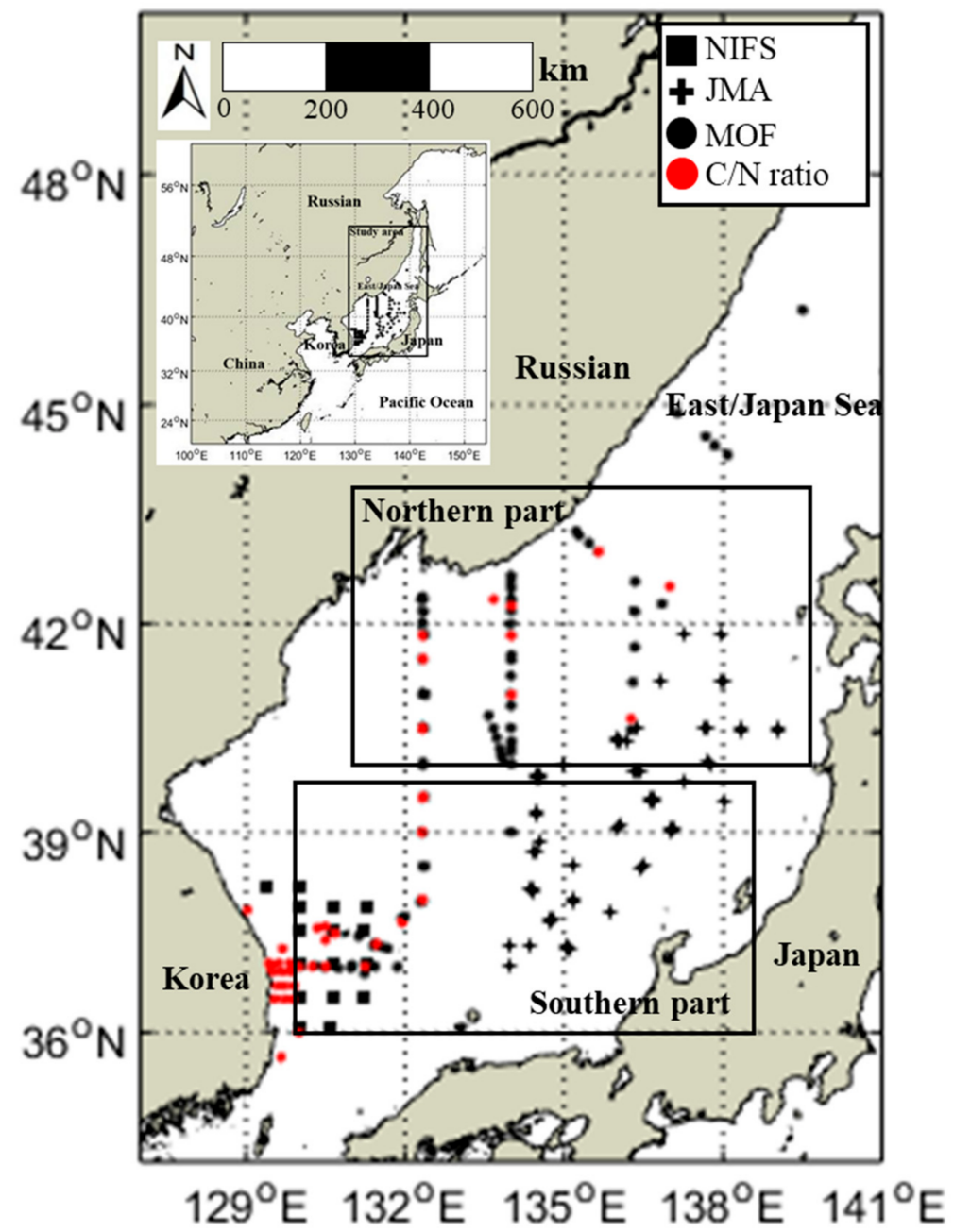

Figure 1. Field measurement stations in the East/Japan Sea (EJS). Squared dots indicate the NIFS (National Institute of Fisheries Sciences, Korea) stations. Cross marks are the JMA (Japan Meteorological Agency, Japan) stations. Dots are the MOF (Ministry of Oceans and Fisheries, Korea) stations. Red dots are the locations of $\mathrm{C} / \mathrm{N}$ ratio measured previously. 
SST and SSC data were extracted from the monthly mapped MODIS-aqua Level-3 products which were remapped as $4 \mathrm{~km} \times 4 \mathrm{~km}$ resolution. The MODIS-aqua-derived ocean color data were obtained from the NASA OBPG website (https:/ / oceandata.sci.gsfc.nasa.gov/). Mixed layer depths (MLD) of the EJS have obtained from ECCO (Estimating the Circulation and Climate of the Ocean) website (http://www.ecco-group.org/).

\subsection{The Regional SSN Algorithms for the East/Japan Sea (EJS)}

A regional SSN algorithm was modified in the present study from previous studies since the algorithm was designed for the Northern Pacific Ocean [36,39]. To develop the SSN algorithm for the northern and southern EJS, SST and SSC data from MODIS-aqua L3 were extracted from the same location, matched with field-measured stations (Figure 1). We used a total of 576 field-measured data for developing the regional SSN algorithm. We divided the northern and southern parts of EJS based on $40^{\circ} \mathrm{N}$ which is a general location of Sub Polar Front (SPF) in the EJS [18,19]. The SSN algorithms as a function of SST and SSC for the northern (1) and southern (2) parts of the EJS are as follows:

$$
\begin{aligned}
& \mathrm{SSN}_{\text {Northern }}=12.4-0.03039 \times \mathrm{SST}^{2}-1.199 \times \mathrm{SST}+0.2739 \times \mathrm{SSC}^{2}-2.781 \times \mathrm{SSC} \\
& \mathrm{SSN}_{\text {Southern }}=12.31+0.01246 \times \mathrm{SST}^{2}-0.7729 \times \mathrm{SST}+0.1751 \times \mathrm{SSC}^{2}-1.508 \times \mathrm{SSC}
\end{aligned}
$$

\subsection{Annual New Production Algorithm for the East/Japan Sea (EJS)}

The annual new production algorithm for the EJS was also modified from Goes et al. [39] which was developed for the Northern Pacific Ocean. The annual new production can be estimated using the relationship $P_{N}=R \Delta N$, where $R$ is carbon to nitrogen $(C / N)$ ratio in the phytoplankton and $\Delta N$ is the difference between the highest SSN concentration in winter before phytoplankton bloom and the lowest SSN concentration in summer at the end of phytoplankton bloom in the EJS. Mainly, we modified the three parameters in the algorithm for annual new production in the EJS. First, we changed the $\mathrm{R}$ values for the EJS. Commonly, the $\mathrm{C} / \mathrm{N}$ ratio in the Redfield ratio is 6.7 in the ocean. However, we used different $\mathrm{C} / \mathrm{N}$ ratios in the northern and southern parts of the EJS based on the field-measured $\mathrm{C} / \mathrm{N}$ ratios of 7.1 and 8.4, respectively, which were obtained from several other cruises in the various regions of EJS during April-October, 2012-2017 (Figure 1; unpublished data). Secondly, $\Delta N=\left[N_{M}-\right.$ $\left.\mathrm{N}_{\mathrm{A}}\right] \times\left[\mathrm{MLD}_{(\mathrm{M})}-\mathrm{MLD}_{(\mathrm{A})}\right]$ was used in this study, where $\mathrm{N}_{\mathrm{M}}$ and $\mathrm{N}_{\mathrm{A}}$ are the concentrations of nitrate and $M_{L} D_{M}$ and $M L D_{A}$ are MLD in March and August, respectively. The nitrate flux through MLD is the highest in February in the southern EJS [33] and phytoplankton bloom normally starts in March in the entire EJS [16]. Thirdly, MLD was used in this study instead of the nitracline depths because most of the phytoplankton live in the MLD, can consume nitrate in the absence of light [31], and MLD is strongly related with phytoplankton bloom [24].

\section{Results}

\subsection{A Regional Algorithm for the Sea Surface Nitrate (SSN) in the East/Japan Sea (EJS)}

The field-measured SSN data were collected for a regional SSN algorithm in the EJS. Before modification, a relationship between SST from satellite and field-measured SSN concentrations in the northern and southern parts of the EJS was obtained (Figure 2). SSN has a significant relationship with SST in the northern part $\left(r^{2}=0.86, y=0.0242 x^{2}-0.8602 x+7.4374\right)$ and the southern part $\left(r^{2}=0.85\right.$, $y=0.0162 x^{2}-0.797 x+10.169$ ) of the EJS (Figure 2). The SSN is almost depleted over $10{ }^{\circ} \mathrm{C}$ and $15^{\circ} \mathrm{C}$ in the northern and the southern parts of the EJS, respectively. 


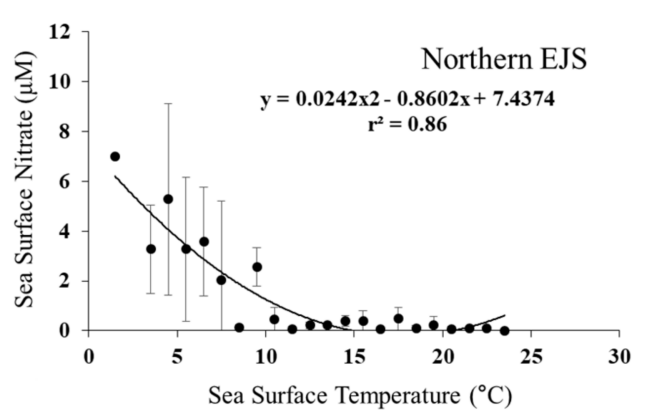

(a)

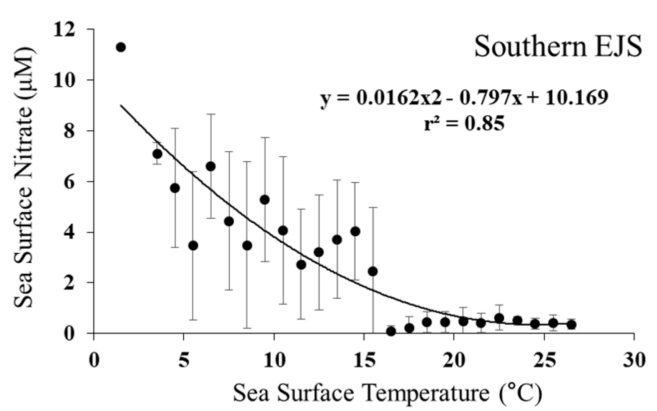

(b)

Figure 2. Relationships between Sea Surface Nitrate (SSN) and Sea Surface Temperature (SST) in the northern (a) and southern (b) East/Japan Sea.

In Figure 3, the estimated SSN concentrations from the SSN algorithms and field-measured SSN concentrations were plotted with $95 \%$ prediction bounds in the northern and southern parts of the EJS. The estimated SSN concentrations matched well with the field-measured SSN concentrations in the northern part $\left(y=0.9495 x, r^{2}=0.52, p<0.01, n=96\right)$ and the southern part $(y=1.0326 x$, $r^{2}=0.55, p<0.01, n=480$ ) of the EJS. In comparison, the regression curves presented with blue lines between the estimated SSN concentrations from the previous algorithm [38,39] and field-measured SSN concentrations indicated no effective matches in the northern $\left(y=0.2453 x, r^{2}=0.40\right)$ and southern $\left(y=0.556 x, r^{2}=0.51\right)$ parts of the EJS.

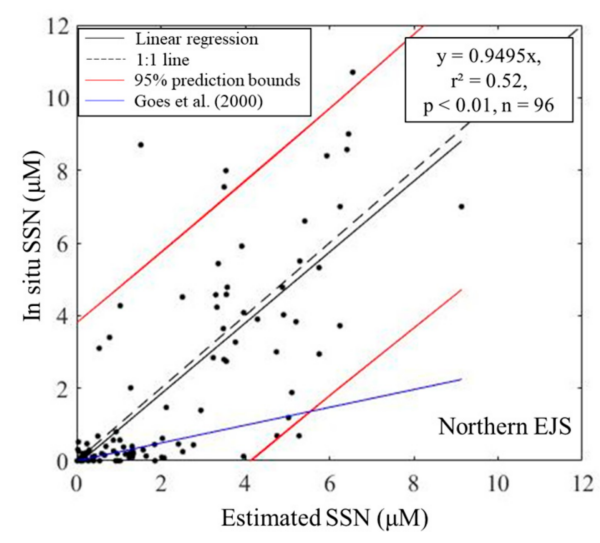

(a)

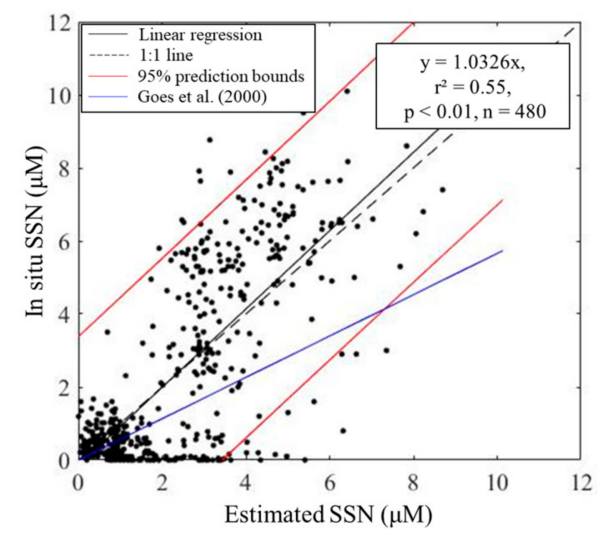

(b)

Figure 3. Correlations between field-measured Sea Surface Nitrate (SSN) and estimated SSN in the northern (a) and southern (b) East/Japan Sea. Dashed lines represent 1:1 lines. Red lines represent the 95\% prediction bounds. Blue lines show the regression curves between in situ SSN and estimated SSN from the algorithm developed by Goes et al. (2000).

\subsection{The Monthly Sea Surface Nitrate (SSN) Concentration in the East/Japan Sea (EJS)}

The monthly climatological images of SSN in the entire EJS are shown in Figure 4. In general, the SSN concentration in the entire EJS had a strong seasonal trend, with the highest SSN concentration during February-March the lowest concentration during June-August (Figure 4). 

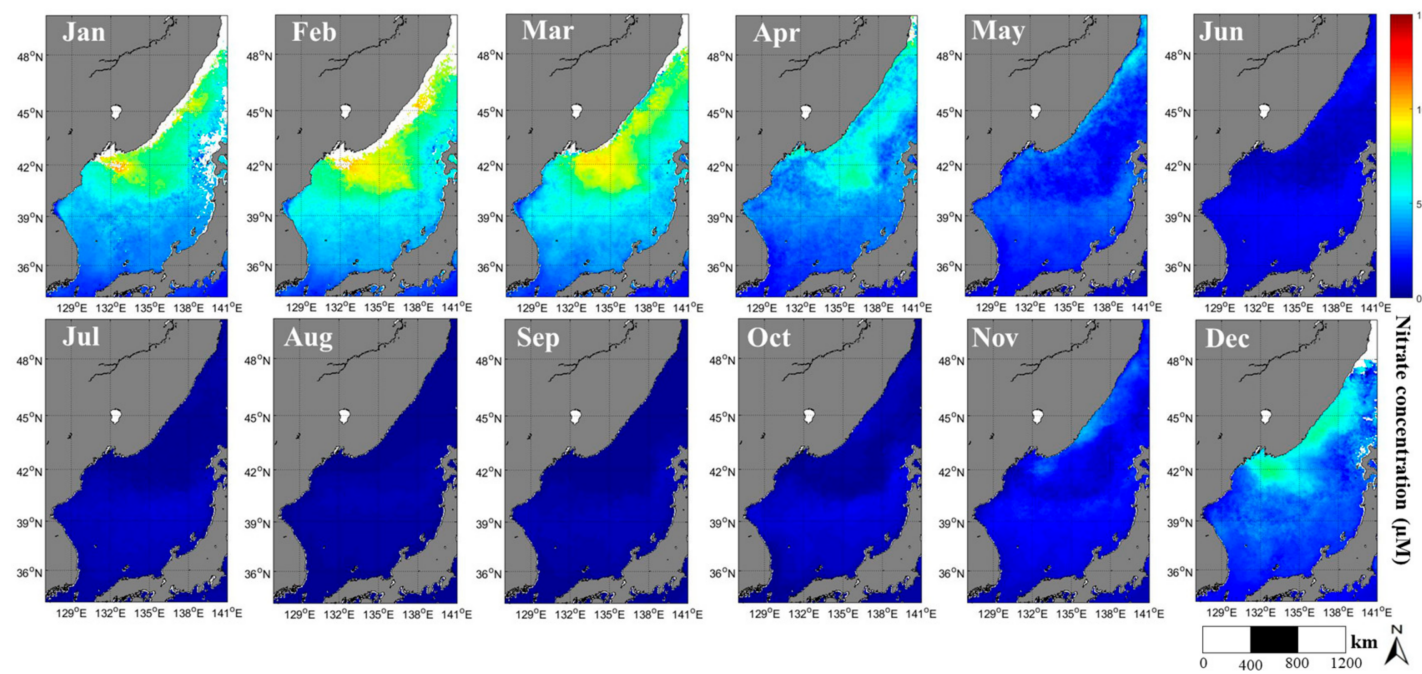

Figure 4. Climatological monthly images of Sea Surface Nitrate (SSN) in the East/Japan Sea (EJS).

The monthly averaged SSN concentrations in the northern and southern parts of the EJS are shown in Figure 5. The SSN concentrations are $0.2-8.7 \mu \mathrm{M}$ and $0.2-5.7 \mu \mathrm{M}$ in the northern and southern parts of the EJS during the study period, respectively. The SSN concentrations are significantly higher in the northern part than the southern part in the EJS ( $t$-test, $p<0.01)$ and they have no specific trend for inter-annual variation during the study period.

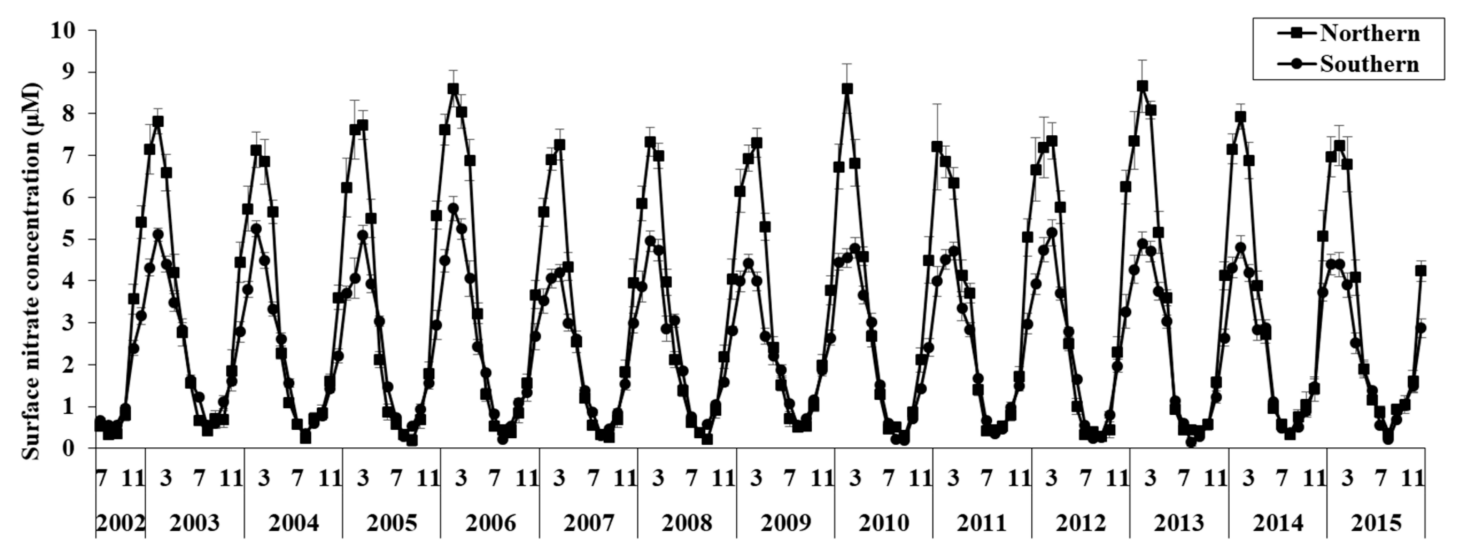

Figure 5. Time series of monthly values in Sea Surface Nitrate (SSN) for the northern and southern East/Japan Sea (EJS) from July 2002 to December 2015.

The annual SSN concentrations in the northern and southern parts of the EJS are shown in Figure 6. The annual SSN concentrations in the northern and southern parts of the EJS were observed to range from $5.8 \mu \mathrm{M}$ to $6.8 \mu \mathrm{M}$ and from $2.9 \mu \mathrm{M}$ to $3.4 \mu \mathrm{M}$, respectively. 

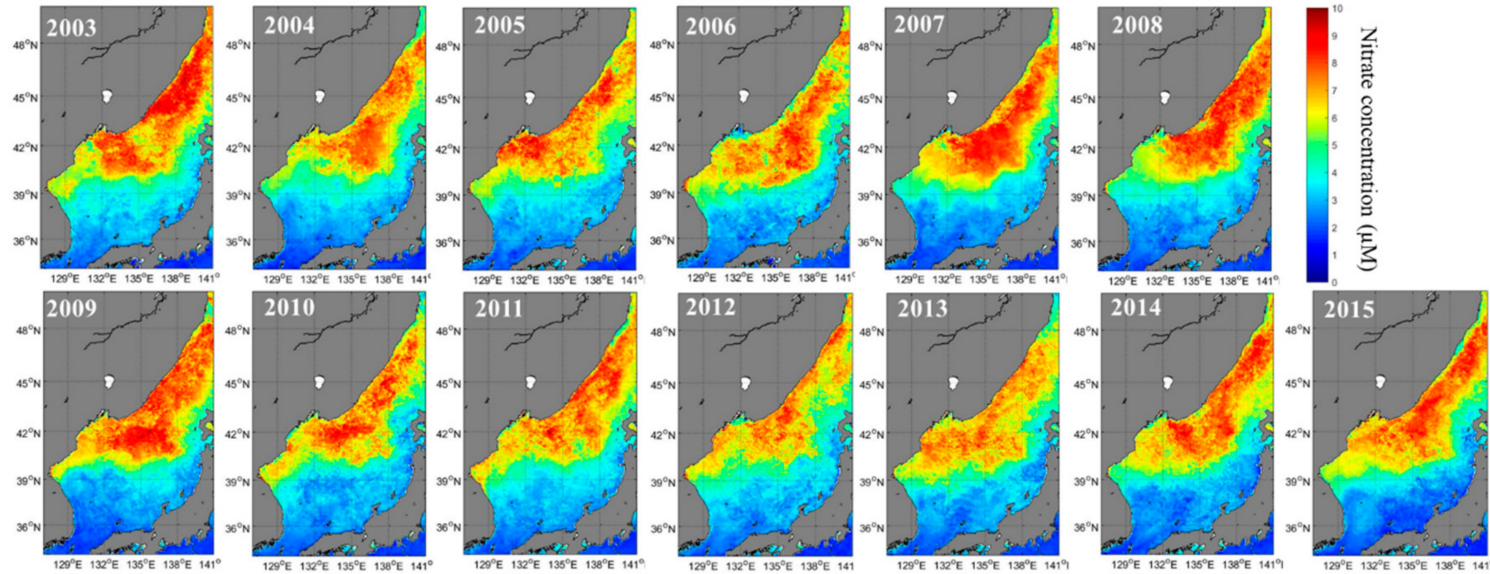

Figure 6. Long-term pattern of the annual Sea Surface Nitrate (SSN) in the East/Japan Sea (EJS) from 2003 to 2015.

\subsection{Long-Term Variation of the Annual New Production in the East/Japan Sea (EJS)}

Our results for the new production are based on models that are temperature-dependent since SSN from the northern and southern parts of the EJS are estimated from SST, SSC, and MLD that have explicit temperature dependence. For a spatial variation, the images of the annual new production in the EJS from 2003 to 2015 have appeared in Figure 7. Although the annual new production varies annually, it is noticeably high in the south of Vladivostok and generally low in the northern region $\left(>43^{\circ} \mathrm{N}\right)$ in the EJS during the study period. The annual new production ranges from $57.4 \mathrm{~g} \mathrm{C} \mathrm{m}^{-2}$ year ${ }^{-1}$ in 2008 to $127.4 \mathrm{~g} \mathrm{C} \mathrm{m}^{-2}$ year $^{-1}$ in 2006 in the northern part and ranges from $52.4 \mathrm{~g} \mathrm{C} \mathrm{m}^{-2}$ year $^{-1}$ in 2007 to $83.3 \mathrm{~g} \mathrm{C} \mathrm{m}^{-2}$ year $^{-1}$ in 2005 in the southern part of the EJS, respectively.
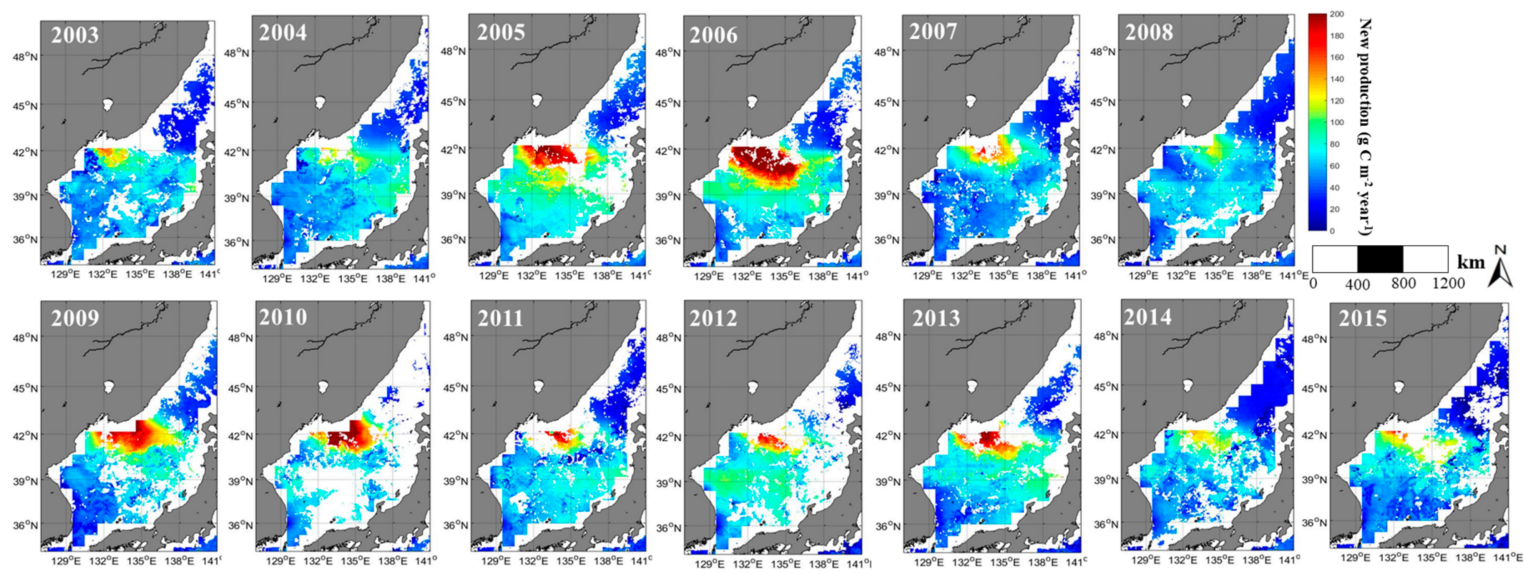

Figure 7. Long-term pattern of the annual new production in the East/Japan Sea (EJS) from 2003 to 2015.

The anomalies of the annual new production in the EJS were estimated for the long-term variation study (Figure 8). Generally, the northern and southern parts of the EJS have the same phase of annual new production anomaly but sometimes they have different phases. The negative phase of annual new production anomaly appears in 2003, 2004, 2007, 2008, 2014, and 2015 in the entire EJS. The positive phase of annual new production anomaly appears in 2005, 2006, 2010, and 2013 in the entire EJS. In 2009, 2011, and 2012, the annual new production anomalies show different phases in the northern and the southern EJS. During the study period, no specific trend in annual new production anomaly was observed in the northern and southern EJS. 


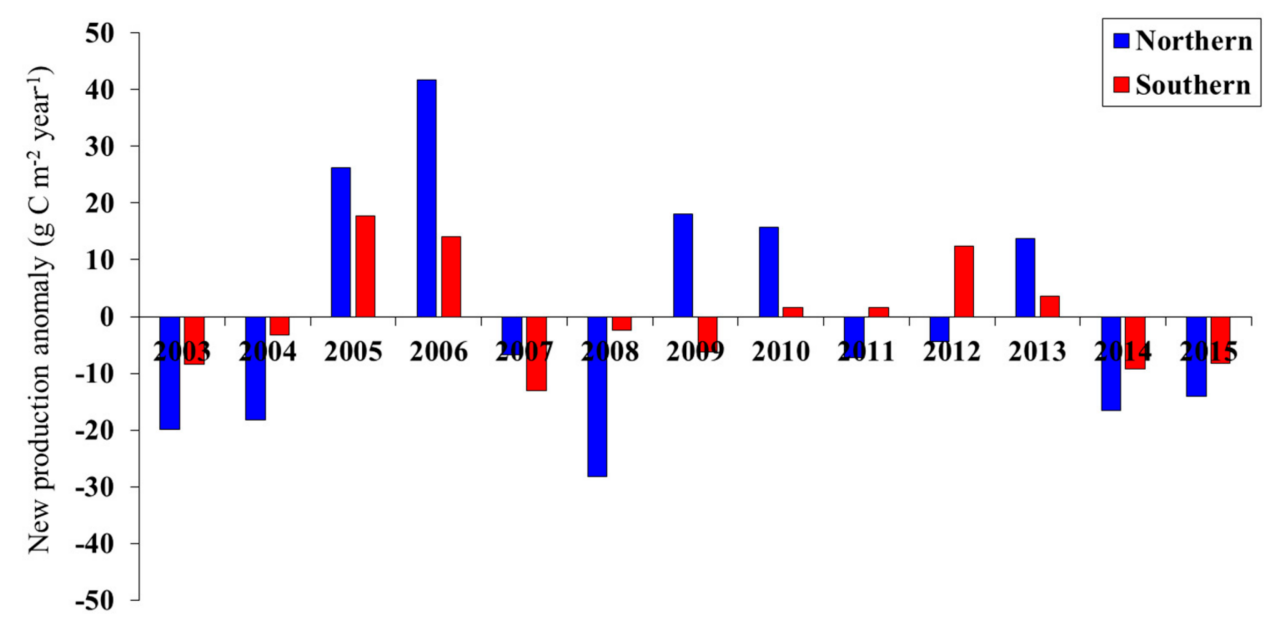

Figure 8. Anomalies of the annual new productions in the northern and southern East/Japan Sea (EJS) during the study period. The blue color bars and red color bars represent the northern and southern East/Japan Sea (EJS), respectively.

To find a major controlling factor for the inter-annual variation of the annual new production in the EJS, the annual new production and the SST in March were plotted in Figure 9. Strong negative relationships were found between the annual new production and the SST in March in the northern $\left(y=-37.201 x+234.97, r^{2}=0.42, p<0.01, n=13\right)$ and the southern $\left(y=-13.277 x+196.79, r^{2}=0.49\right.$, $p<0.01, n=13)$ parts in the EJS.

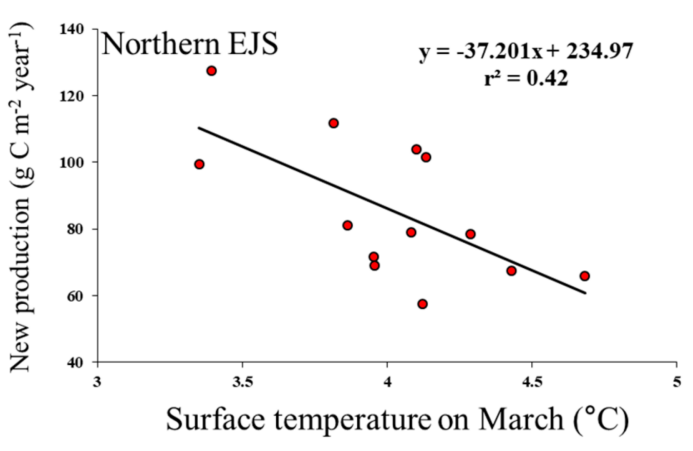

(a)

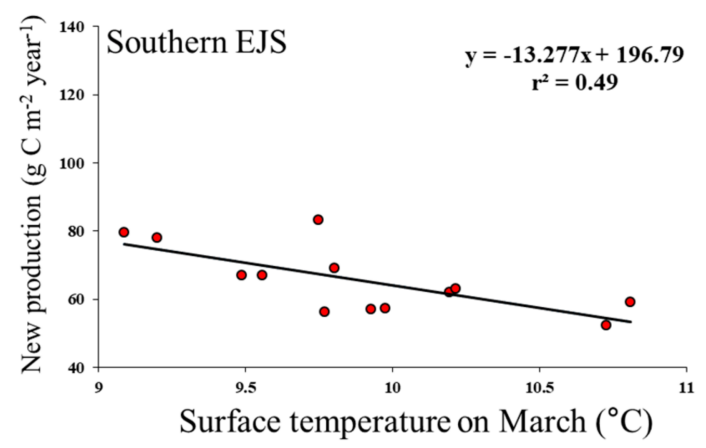

(b)

Figure 9. Relationships between the annual new production and Sea Surface Temperature (SST) in March in the northern (a) and southern (b) East/Japan Sea (EJS).

\section{Discussion}

\subsection{The Spatial and Temporal Variation of Sea Suface Nitrate (SSN) in the East/Japan Sea (EJS)}

To date, there is very limited knowledge on the distribution and characteristics of nitrate in the EJS [26,31,41,42], although nitrate is strongly associated with the growth of phytoplankton and thus with primary production of phytoplankton [36]. In this study, the SSN concentrations of the northern and southern EJS were estimated from the regional SSN algorithm with MODIS-derived SST and SSC for finding spatial and temporal variation of SSN concentration.

The SSN concentrations in the entire EJS are 2.2-8.7 $\mu \mathrm{M}$ and $0.2-1.2 \mu \mathrm{M}$ in winter and summer, respectively. In previous studies, nitrate concentration in surface waters showed large variations in the EJS. Nitrate concentrations were 5.8-14.8 $\mu \mathrm{M}$ in the entire EJS during winter [43]. In summer, 
low nitrate concentrations were observed in the Ulleung Basin $(<1 \mu \mathrm{M})$ and $0.3-5.5 \mu \mathrm{M}$ in the northern EJS [43-45].

The averaged SSN concentrations from 2002 to 2015 are $3.2 \mu \mathrm{M}(\mathrm{S} . \mathrm{D} \pm 2.7 \mu \mathrm{M})$ and $2.3 \mu \mathrm{M}$ $(\mathrm{S} . \mathrm{D} \pm 1.6 \mu \mathrm{M})$ in the northern and southern parts in the EJS, respectively (Figure 5). The average annual SSN concentrations were $6.3 \mu \mathrm{M}($ S.D. $= \pm 0.3 \mu \mathrm{M})$ and $3.2 \mu \mathrm{M}(\mathrm{S} . \mathrm{D} \pm 0.2 \mu \mathrm{M})$ in the northern and southern parts of the EJS, respectively (Figure 6). The SSN concentrations were relatively higher in the northern part compared to those in the other parts of our study area (Figure 4). Generally, the SSN concentration has negative relationships with SST and biomass of phytoplankton [38,39]. The relatively high SSN concentrations in the northern part of the EJS are probably associated with the cold water input from the deep water [34] and hence relatively lower primary productivity of phytoplankton $[6,13,46,47]$. In particular, the surface nutrient concentration is higher in the western Japan Basin than the Ulleung Basin and the eastern Japan Basin, which is probably related to a deeper vertical mixing in the western Japan Basin during winter [34]. The nutrient input into surface layer would be declined by a strong stratification, which makes a weak vertical mixing under ongoing climate change [28]. Recently, Jo et al. [7] reported that the increasing SST in the east coast of Korea is much faster than the global average. Indeed, decreasing field-measured nitrate concentration was observed in the southwestern EJS (i.e., Ulleung Basin) over the recent decade from 2003 to 2012 [6], though we did not observe the decreasing trend in SSN concentration in the entire EJS. A long-term monitoring study is needed to detect any changes in the nitrate concentration in the EJS under ongoing climate change.

\subsection{The Spatial and Temporal Variation of Annual New Production in the East/Japan Sea (EJS)}

The annual new production averaged from 2003 to 2015 is $75.6 \mathrm{~g} \mathrm{C} \mathrm{m}^{-2}$ year $^{-1}$ (S.D $= \pm 19.0 \mathrm{~g}$ $\mathrm{C} \mathrm{m}^{-2}$ year $^{-1}$ ) in the entire EJS (Figure 7). The average annual new productions are $85.7 \mathrm{~g} \mathrm{C} \mathrm{m}^{-2}$ year $^{-1}\left(\mathrm{~S} . \mathrm{D}= \pm 10.1 \mathrm{~g} \mathrm{C} \mathrm{m}^{-2}\right.$ year $\left.^{-1}\right)$ and $65.6 \mathrm{~g} \mathrm{C} \mathrm{m}^{-2}$ year $^{-1}\left(\mathrm{~S} . \mathrm{D}= \pm 4.0 \mathrm{~g} \mathrm{C} \mathrm{m}^{-2}\right.$ year $\left.^{-1}\right)$ in the northern and southern parts of the EJS, respectively. For comparison, the annual new productions previously reported in the EJS were summarized in Table 2. Based on oxygen consumption rate, Hahm and Kim [34] estimated $99 \mathrm{~g} \mathrm{C} \mathrm{m}^{-2}$ year $^{-1}$ for the annual new production in the Japan Basin. Hahm and $\mathrm{Kim}$ [31] reported $64 \mathrm{~g} \mathrm{C} \mathrm{m}^{-2}$ year $^{-1}$ for the annual new production in the Ulleung Basin based on ${ }^{3} \mathrm{He}$ flux and Kim et al. [48] also obtained a similar value (58.7 $\mathrm{g} \mathrm{C} \mathrm{m}^{-2}$ year $\left.{ }^{-1}\right)$ in the same Basin using ${ }^{234} \mathrm{Th} /{ }^{238} \mathrm{U}$ disequilibrium measurements. For the entire EJS, Goes et al. [39] reported relatively lower annual new productions ranging from 30 to $50 \mathrm{~g} \mathrm{C} \mathrm{m}^{-2}$ year $^{-1}$, although they used a similar algorithm for the annual new production. This difference in the annual production in the EJS between the current study and Goes et al. [39] could be due to our modified algorithm (e.g., higher C/N ratios and MLD in the method section). In general, the annual new productions in this study are within the range of various regions in the EJS reported previously. However, the ${ }^{13} \mathrm{C}$-based estimations for the annual new production were substantially different from those in other methods ([35]; Table 2). Kwak et al. [35] reported considerably higher annual new production $\left(145.6 \mathrm{~g} \mathrm{C} \mathrm{m}^{-2}\right.$ year $\left.^{-1}\right)$ in the Ulleung Basin from monthly field measurements from May 2010 to June 2011. For a direct comparison, the annual new production derived from our data in the Ulleung Basin was $61.8 \mathrm{~g} \mathrm{C} \mathrm{m}^{-2}$ year $^{-1}$ during the same period from May 2010 to June 2011, which is approximately 40\% of the field-measured annual new production from Kwak et al. ([35]; Table 2). The higher annual new production from Kwak et al. [49] might be caused by an additional nitrate input upward into the euphotic depth through MLD which was not considered in this study [36]. For a comparison, we estimated the amount of nitrate input from upward vertical flux based on the field measurement data in the Ulleung Basin [35]. The nitrate upward flux was calculated from the integrated nitrate uptake rates in the mixed layer depth and vertical diffusion coefficient [50]. The average nitrate upward flux estimated in this study was $90.4 \pm 78.6 \mu \mathrm{g}$-at $\mathrm{N} \mathrm{m}^{-2} \mathrm{~h}^{-1}$ in the Ulleung Basin, which is within the range of 4-182 $\mu \mathrm{g}$-at $\mathrm{N}$ $\mathrm{m}^{-2} \mathrm{~h}^{-1}$ reported previously in June, October, and November in the Ulleung Basin and sub-polar front regions in the EJS $[35,51,52]$. Based on the monthly nitrate upward flux, an additional annual 
new production is estimated to be at $73.2 \mathrm{~g} \mathrm{C} \mathrm{m}^{-2}$ year ${ }^{-1}$ in the Ulleung Basin. This value contributes approximately $50 \%$ to the field-measured annual new production from Kwak et al. [35]. In addition, atmospheric deposition of nitrate could be another source of nitrate in the EJS since it supports 10 15\% of annual new production in the southwestern EJS [53,54]. However, our estimated annual new productions solely depend on the nitrate inputs from convective mixing in the northern and southern EJS during the winter. Therefore, annual new productions from the additional nitrate inputs from the nitrate upward flux through the MLD and atmospheric deposition during the year long period, which were not considered in this study, could cause the difference in the annual new production between satellite-derived method in this study and the field measurements in Kwak et al. [35].

Table 2. Comparison of the annual new production in the East/Japan Sea (EJS).

\begin{tabular}{cccc}
\hline $\begin{array}{c}\text { New Production } \\
\left(\mathbf{g ~ C ~} \mathbf{~ m}^{-\mathbf{2}} \text { year }^{-\mathbf{1}} \mathbf{)}\right.\end{array}$ & Locations & Methods & Reference \\
\hline 30 to 50 & Entire EJS & Satellite & Goes et al. [39] \\
99 & Japan Basin & Oxygen consumption rate & Hahm and Kim [34] \\
54 & Ulleung Basin & ${ }^{3} \mathrm{He}$ flux & Hahm and Kim [31] \\
58.7 & Ulleung Basin & ${ }^{234} \mathrm{Th} /{ }^{238} \mathrm{U}$ & Kim et al. [48] \\
145.6 & Ulleung Basin & ${ }^{15} \mathrm{~N}$ & Kwak et al. [35] \\
165.3 & Ulleung Basin & Satellite & Joo et al. [6] \\
65.6 & Southern part of the EJS & Satellite & This study \\
85.7 & Northern part of the EJS & Satellite & This study \\
\hline
\end{tabular}

\section{Summary and Conclusions}

In this study, we estimated the SSN and the annual new production using the regional algorithm and MODIS-derived ocean color data and determined the temporal and spatial variation of them in the EJS from 2003 to 2015 (Figures 5-7). The average annual new production in the northern part was significantly higher $(t$-test, $p<0.01)$ than the southern part of the EJS. In the northern part of the EJS, deeper mixed layer depths during winter could provide more nitrate concentration into the euphotic zones from deep waters [43]. The annual new production had no specific trend in the EJS over the observation period from 2003 to 2015. The annual new productions in the northern and southern EJS were strongly negatively associated with the SST in March (Figure 9). The relationships between the annual new productions and the SST in March (Figure 9) showed a relatively more rapid slope in the northern part $(y=-37.201 x+234.97)$ than in the southern part $(y=-13.277 x+196.79)$. This suggests that the annual new production in the northern part of the EJS could be more sensitive towards ongoing warming trend compared to the southern EJS. The new production results in the present study are based on temperature-dependent models, since the SSN for the EJS are estimated from temperature-dependent SST, SSC, and MLD. A detailed analysis with spatial and temporal scales on annual new production and nitrate dynamics is highly recommended to understand the potential influence of global warming on the environmental conditions and consequently on the marine ecosystem in the EJS.

Author Contributions: Conceptualization, H.J., S.H.S. and S.H.L.; Data curation, H.J. and D.L.; Formal analysis, H.J., S.H.S. and S.H.L.; Investigation, D.L.; Methodology, S.H.S.; Validation, D.L.; Writing—original draft, H.J. and S.H.L.; Writing-review \& editing, S.H.L.

Acknowledgments: This research was a part of the projects entitled "Development of the integrated data processing system for GOCI-II" and "Long-term change of structure and function in marine ecosystems of Korea" funded by the Ministry of Oceans and Fisheries, Korea.

Conflicts of Interest: The authors declare no conflict of interest. 


\section{References}

1. Kim, K.-R.; Kim, K.; Kang, D.-J.; Park, S.Y.; Park, M.-K.; Kim, Y.-G.; Min, H.S.; Min, D. The East Sea (Japan Sea) in change: A story of dissolved oxygen. Mar. Technol. Soc. J. 1999, 33, 15-22. [CrossRef]

2. Kim, K.; Kim, K.-R.; Min, D.-H.; Volkov, Y.; Yoon, J.-H.; Takematsu, M. Warming and structural changes in the East (Japan) Sea: A clue to future changes in global oceans? Geophys. Res. Lett. 2001, 28, 3293-3296. [CrossRef]

3. Kang, D.J.; Park, S.; Kim, Y.G.; Kim, K.; Kim, K.-R. A moving-boundary box model (MBBM) for oceans in change: An application to the East/Japan Sea. Geophys. Res. Lett. 2003, 30, 1299. [CrossRef]

4. Chiba, S.; Aita, M.N.; Tadokoro, K.; Saino, T.; Sugisaki, H.; Nakata, K. From climate regime shifts to lower-trophic level phenology: Synthesis of recent progress in retrospective studies of the western North Pacific. Prog. Oceanogr. 2008, 77, 112-126. [CrossRef]

5. $\quad$ Lee, S.H.; Son, S.; Dahms, H.-U.; Park, J.W.; Lim, J.-H.; Noh, J.-H.; Kwon, J.-I.; Joo, H.T.; Jeong, J.Y.; Kang, C.-K. Decadal changes of phytoplankton Chl-a in the East Sea/Sea of Japan. Oceanology 2014, 6, 771-779. [CrossRef]

6. Joo, H.; Park, J.W.; Son, S.; Noh, J.H.; Jeong, J.Y.; Kwak, J.H.; Saux-Picart, S.; Choi, C.H.; Kang, C.K.; Lee, S.H. Long-term annual primary production in the Ulleung Basin as a biological hot spot in the East/Japan Sea. J. Geophys. Res. 2014, 119, 3002-3011. [CrossRef]

7. Jo, Y.H.; Breaker, L.C.; Tseng, Y.-H.; Yeh, S.-W. A temporal multiscale analysis of the waters off the east coast of South Korea over the past four decades. Terr. Atmos. Ocean. Sci. 2014, 25, 415-434. [CrossRef]

8. Lee, S.H.; Kang, C.-K.; Lee, C.-I.; Kwak, J.H. Current status of the East Sea Ecosystem in a changing world. Deep Sea Res. Part II 2017, 146, 101-103. [CrossRef]

9. Kang, S.; Kim, S.; Bae, S.-W. Changes in ecosystem components induced by climate variability off the eastern coast of the Korean Penunsula during 1960-1990. Prog. Oceanogr. 2000, 47, 205-222. [CrossRef]

10. Lee, J.-Y.; Kang, D.-J.; Kim, I.-N.; Rho, T.; Lee, T.; Kang, C.-K.; Kim, K.-R. Spatial and temporal variability in the pelagic ecosystem of the East Sea (Sea of Japan): A review. J. Mar. Syst. 2009, 78, 288-300. [CrossRef]

11. Kang, Y.S.; Jung, S.; Zuenko, Y.; Choi, I.; Dolganova, N. Regional differences in the response of mesozooplankton to oceanographic regime shifts in the northeast Asian marginal seas. Prog. Oceanogr. 2012, 97, 120-134. [CrossRef]

12. Joo, H.; Son, S.; Park, J.-W.; Kang, J.J.; Jeong, J.-Y.; Lee, C.I.; Kang, C.-K.; Lee, S.H. Long-term pattern of primary productivity in the East/Japan Sea based on ocean color data derived from MODIS-aqua. Remote Sens. 2016, 8, 25. [CrossRef]

13. Jung, H.K.; Rahman, S.M.; Park, J.-W.; Kang, C.-K.; Park, S.-Y.; Lee, S.H.; Park, H.J.; Kim, H.-W.; Lee, C.I. The influence of climate regime shifts on the marine environment and ecosystems in the East Asian Marginal Seas and their mechanisms. Deep-Sea Res. Part II 2017, 143, 110-120. [CrossRef]

14. Zhang, C.I.; Lee, J.B.; Kim, S.; Oh, J.H. Climatic regime shifts and their impacts on marine ecosystem and fisheries resources in Korean waters. Prog. Oceanogr. 2000, 47, 171-190. [CrossRef]

15. Zhang, C.I.; Lee, J.B.; Seo, Y.I.; Yoon, S.C.; Kim, S. Variations in the abundance of fisheries resources and ecosystem structure in the Japan/East Sea. Prog. Oceanogr. 2004, 61, 245-265. [CrossRef]

16. Tian, Y.; Kidokoro, H.; Watanabe, T.; Iguchi, N. The late 1980s regime shift in the ecosystem of Tsushima warm current in the Japan/East Sea: Evidence from historical data and possible mechanisms. Prog. Oceanogr. 2008, 77, 127-145. [CrossRef]

17. Tian, Y.; Kidokoro, H.; Watanabe, T.; Igeta, Y.; Sakaji, H.; Ino, S. Response of yellowtail, Seriola quinqueradiata, a key large predatory fish in the Japan Sea, to sea water temperature over the last century and potential effect of global warming. J. Mar. Syst. 2012, 91, 1-10. [CrossRef]

18. Kim, T.; Yoon, J.-H. Seasonal variation of upper layer circulation in the northern part of the East/Japan Sea. Cont. Shelf Res. 2010, 30, 1283-1301. [CrossRef]

19. Park, K.-A.; Ullman, D.; Kim, K.; Chung, J.; Kim, K.-R. Spatial and temporal variability of satellite-observed subpolar front in the East/Japan Sea. Deep-Sea Res. Part I 2007, 54, 453-470. [CrossRef]

20. Kwak, J.H.; Han, E.; Lee, S.H.; Park, H.J.; Kang, C.K. A consistent structure of phytoplankton communities across the warm-cold regions of the water mass on a meridional transect in the East/Japan Sea. Deep-Sea Res. Part II 2017, 143, 36-44. [CrossRef]

21. Onitsuka, G.; Yanagi, T. Differences in ecosystem dynamics between the northern and southern parts of the Japan Sea: Analyses with two ecosystem models. J. Oceanogr. 2005, 61, 415-433. [CrossRef] 
22. Yoo, S.; Park, J. Why is the southwest the most productive region of the East Sea/Sea of Japan? J. Mar. Syst. 2009, 78, 301-315. [CrossRef]

23. Kim, D.; Yang, E.J.; Kim, K.H.; Shin, C.-W.; Park, J.; Yoo, S.; Hyun, J.-H. Impact of an anticyclonic eddy on the summer nutrient and chlorophyll $a$ distributions in the Ulleung Basin, East Sea (Japan Sea). ICES J. Mar. Sci. 2012, 69, 23-29. [CrossRef]

24. Lim, S.; Jang, C.J.; Oh, I.S.; Park, J. Climatology of the mixed layer depth in the East/Japan Sea. J. Mar. Syst. 2012, 96-97, 1-14. [CrossRef]

25. Zentara, S.-J.; Kamykowski, D. Latitudinal relationships among temperature and selected plant nutrients along the west coast of north and South America. J. Mar. Res. 1977, 35, 321-337.

26. Switzer, A.C.; Kamykowski, D.; Zentara, S.J. Mapping nitrate in the global ocean using remotely sensed sea surface temperature. J. Geophys. Res. 2003, 108. [CrossRef]

27. Son, S.; Platt, T.; Bouman, H.; Lee, D.; Sathyendranath, S. Satellite observation of chlorophyll and nutrients increase induced by Typhoon Megi in the Japan/East Sea. Geophys. Res. Lett. 2006, 33. [CrossRef]

28. Laws, E.A.; Falkowski, P.G.; Smith, W.O.; Ducklow, H.; McCarthy, J.J. Temperature effects on export production in the open ocean. Glob. Biogeochem. Cycles 2000, 14, 1231-1246. [CrossRef]

29. Steinacher, M.; Joos, F.; Frolicher, T.L.; Bopp, L.; Cadule, P.; Cocco, V.; Doney, S.C.; Gehlen, M.; Lindsay, K.; Moore, J.K.; et al. Projected 21st century decrease in marine productivity: A multi-model analysis. Biogeosciences 2010, 7, 979-1005. [CrossRef]

30. Henson, S.A.; Beaulieu, C.; Lampitt, R. Observing climate change trends in ocean biogeochemistry: When and where. Glob. Chang. Biol. 2016, 22, 1561-1571. [CrossRef] [PubMed]

31. Dugdale, R.C.; Goering, J.J. Uptake of new and regenerated forms of nitrogen in primary productivity. Limnol. Oceanogr. 1967, 12, 196-206. [CrossRef]

32. Eppley, R.W.; Peterson, B.J. Particulate organic matter flux and planktonic new production in the deep ocean. Nature 1979, 282, 677-680. [CrossRef]

33. Hahm, D.; Kim, K.R. An estimation of the new production in the southern East Sea using helium isotopes. J. Korean Soc. Oceanogr. 2001, 36, 19-26.

34. Hahm, D.; Kim, K.R. Observation of bottom water renewal and export production in the Japan basin, East/Japan Sea using tritium and helium isotopes. Ocean Sci. J. 2008, 43, 39-48. [CrossRef]

35. Kwak, J.H.; Lee, S.H.; Park, H.J.; Choy, E.J.; Jeong, H.D.; Kim, K.-R.; Kang, C.-K. Monthly measured primary and new productivities in the Ulleung Basin as a biological "hot spot" in the East/Japan Sea. Biogeosciences 2013, 10, 4405-4417. [CrossRef]

36. Joo, H.; Lee, D.; Kang, J.J.; Lee, J.H.; Jeong, J.-Y.; Son, S.; Kwon, J.-I.; Lee, S.H. Inter-annual variation of the annual new production of phytoplankton in the southwestern East/Japan Sea estimated from satellite-derived surface nitrate concentration. J. Coast. Res. 2018. accepted.

37. Chavez, F.P.; Service, S.K.; Buttrey, S.E. Temperature-nitrate relationships in the central and eastern tropical Pacific. J. Geophys. Res. Oceans 1996, 101, 20553-20563. [CrossRef]

38. Garside, C.; Garside, J.C. Euphotic-zone nutrient algorithms for the NABE and EqPac study sites. Deep-Sea Res. 1995, 42, 335-342. [CrossRef]

39. Goes, J.I.; Saino, T.; Oaku, H.; Jiang, D.L. A method for estimating sea surface nitrate concentrations from remotely sensed SST and chlorophyll a-A case study for the north pacific ocean using OCTS/ADEOS data. IEEE Trans. Geosci. Remote. 1999, 37, 1633-1644. [CrossRef]

40. Goes, J.I.; Saino, T.; Oaku, H.; Ishizaka, J.; Wong, C.S.; Nojiri, Y. Basin scale estimates of sea surface nitrate and new production from remotely sensed sea surface temperature and chlorophyll. Geophys. Res. Lett. 2000, 27, 1263-1266. [CrossRef]

41. Silió-Calzada, A.; Bricaud, A.; Gentili, B. Estimates of sea surface nitrate concentrations from sea surface temperature and chlorophyll concentration in upwelling areas: A case study for the Benguela system. Remote Sens. Environ. 2008, 112, 3173-3180. [CrossRef]

42. Jianping, Y.; Li, L.; Youshao, W.; Jianwei, D. Temporal variability of temperature-nitrate relationship in a coastal region. Chin. J. Oceanogr. 2014, 32, 879-885.

43. Rho, T.; Lee, T.; An, S. Dissolved oxygen and nutrients. In Ocenography of the East Sea (Japan Sea); Chang, K.-I., Zhang, C.-I., Park, C., Kang, D.-J., Ju, S.-J., Lee, S.-H., Wimbush, M., Eds.; Springer: Cham, Switzerland, 2016; pp. 149-168. ISBN 978-3-319-22719-1. 
44. Kaplunenko, D.D.; Lobanov, V.B.; Tishchenko, P.Y.; Shvetsova, M.G. Nitrate in situ measurements in the northern Japan Sea. Deep-Sea Res. II 2013, 86-87, 10-18. [CrossRef]

45. Kwak, J.H.; Lee, S.H.; Hwang, J.; Suh, Y.-S.; Park, H.J.; Chang, K.-I.; Kim, K.-R.; Kang, C.-K. Summer primary productivity and phytoplankton community composition driven by different hydrographic structures in the East/Japan Sea and the western subarctic Pacific. J. Geophys. Res. Ocean. 2014, 119, 4505-4519. [CrossRef]

46. Yamada, K.; Ishizaka, J.; Yoo, S.; Kim, H.-C.; Chiba, S. Seasonal and interannual variability of sea surface chlorophyll a concentration in the Japan/East Sea (JES). Prog. Oceanogr. 2004, 61, 193-211. [CrossRef]

47. Yamada, K.; Ishizaka, J.; Nagata, H. Spatial and temporal variability of satellite primary productivity in the Japan Sea from 1998 to 2002. J. Oceanogr. 2005, 61, 857-869. [CrossRef]

48. Kim, D.; Choi, M.S.; Oh, H.Y.; Song, Y.-H.; Noh, J.-H.; Kim, K.H. Seasonal export fluxes of particulate organic carbon from ${ }^{234} \mathrm{Th} /{ }^{238} \mathrm{U}$ disequilibrium measurements in the Ulleung basin (Tsushima basin) of the East Sea (Sea of Japan). J. Oceanogr. 2011, 67, 577-588. [CrossRef]

49. Kwak, J.H.; Hwang, J.; Choy, E.J.; Park, H.J.; Kang, D.-J.; Lee, T.; Chang, K.-I.; Kim, K.-R.; Kang, C.-K. High primary productivity and f-ratio in summer in the Ulleung basin of the East/Japan Sea. Deep-Sea Res. Part I 2013, 79, 74-85. [CrossRef]

50. King, F.D.; Devol, A.H. Estimates of vertical eddy diffusion through the thermocline from phytoplankton nitrate uptake rates in the mixed layer of the eastern tropical Pacific. Limnol. Oceanogr. 1979, 24, 645-651. [CrossRef]

51. Moon, C.H.; Yang, H.S.; Lee, K.W. Regeneration processes of nutrients in the polar front area of the East Sea. I. Relationship between water mass and nutrient distribution pattern in Autumn. J. Korea Fish. Soc. 1996, 29, 503-526.

52. Moon, C.H.; Yang, S.R.; Yang, H.S.; Cho, H.J.; Lee, S.Y.; Kim, S.Y. Regeneration process of nutrients in the polar front area of the East Sea. IV. Chlorophyll a distribution, new production and the vertical diffusion of nitrate. J. Korea Fish. Soc. 1998, 31, 259-266.

53. Onitsuka, G.; Uno, I.; Yanagi, T. Modeling the effects of atmospheric nitrogen input on biological production in the Japan Sea. J. Oceanogr. 2009, 65, 433-438. [CrossRef]

54. Kang, J.; Cho, B.C.; Lee, C.B. Atmospheric transport of water-soluble ions $\left(\mathrm{NO}_{3}{ }^{-}, \mathrm{NH}_{4}{ }^{+}\right.$, and nss-SO $\left.{ }^{2-}\right)$ to the southern East Sea (Sea of Japan). Sci. Total Environ. 2010, 408, 2369-2377. [CrossRef] [PubMed] 